\title{
Penambahan Ekstrak Pegagan (Centella asiatica) Sebagai Anti kontaminan pada Medium In Vitro Alternatif Perkecambahan Anggrek Dendrobium macrophyllum A. Rich
}

\author{
Ika Nugraheni Ari Martiwi a*, Endang Sri Wahyuni a \\ a Fakultas Sains dan Teknologi UIN Sunan Kalijaga Yogyakarta, Indonesia
}

\begin{tabular}{l}
\hline K A T A K U N C I \\
\hline antikontaminan \\
biji anggrek jamrud \\
D. macrophyllum A. Rich \\
pupuk daun \\
ekstrak ragi \\
ekstrak pegagan
\end{tabular}

\begin{abstract}
A B S T R A K
Kondisi aseptis mutlak diperlukan dalam kultur jaringan tumbuhan. Salah satu strategi untuk meminimalisasi terjadinya kontaminasi adalah dengan menambahkan senyawa antifungi dan antibakteri. Centella asiatica atau pegagan dikenal sebagai salah satu tanaman yang mengandung senyawa yang bersifat antimikrobia dan antifungi, sebagai antioksidan dan antikanker. Penelitian ini bertujuan untuk mengetahui pengaruh ekstrak pegagan yang berpotensi sebagai antikontaminan pada perkecambahan anggrek Dendrobium macrophyllum dalam medium alternatif pupuk daun dan penambahan ekstrak ragi. Penelitian ini menggunakan biji anggrek umur 4 bulan yang ditanam dalam medium VW dan pupuk daun dengan penambahan variasi bahan organik berupa ekstrak ragi dan ekstrak pegagan. Hasil Penelitian menunjukkan bahwa komposisi Media pupuk daun $1,5 \mathrm{~g} / \mathrm{l}$, ekstrak ragi 1,25 g/l, dan ekstrak daun pegagan $5 \%$ merupakan media optimal untuk perkecambahan biji anggrek Dendrobium macrophyllum karena dapat bertahan aseptis, memiliki waktu inisiasi biji berkecambah tercepat, jumlah prosentase perkecambahan terbanyak dan warna protocorm hijau segar.
\end{abstract}

K E Y W O R D S

anti-contaminant emerald orchid seeds

D. macrophyllum A. Rich

foliar fertilizer

yeast extract

Centella asiatica extract

\begin{abstract}
A B S T R A C T
Aseptic conditions of explants is absolutely necessary in plant tissue culture. One of strategies to minimize contamination is adding antimicrobial compounds. Centella asiatica is known as one of the plants containing compounds with antioxidant, anticancer, antibacterial and antifungal properties. This study aimed to determinate the effect of $\mathrm{C}$. asiatica extracts as an anti-contaminant on orchid germination medium. Four months old orchid seeds were planted in medium foliar fertilizer and yeast extract supplemented by $C$. asiatica extract with various concentration and medium VW as a control. The results showed that the optimum media for orchid seeds germination consisted of $1,5 \mathrm{~g} / \mathrm{l}$ of foliar fertilizer, $1,25 \mathrm{~g} / \mathrm{l}$ of yeast extract, $5 \%$ of $\mathrm{C}$. asiatica extract based on germination time, the number of protocorm and the fresh green colour of protocorm as compared with other treatments.
\end{abstract}

TERSEDIA ONLINE 22 Agustus 2016

\author{
1. Pendahuluan \\ Keberhasilan teknik kultur jaringan tumbuhan \\ ditentukan salah satunya oleh kondisi aseptis. Kondisi ini
}

diperlukan karena kontaminasi bakteri atau fungi dapat mengurangi laju pertumbuhan, menghambat perkembangan akar serta menyebabkan kematian eksplan, hal ini dapat terjadi pada semua fase dalam

${ }^{*}$ Corresponding author: Fakultas Sains dan Teknologi UIN Sunan Kalijaga Yogyakarta, Indonesia; Email address: ika_mgl@yahoo.com Published by FMIPA UNSRAT (2016) 
periode kultivasi (Leifert, 2000). Sumber Kontaminasi dapat dikategorikan menjadi 2 yaitu yang berasal dari permukaan dan internal eksplan, serta kontaminan yang diperoleh pada saat prosedur penanaman. Telah banyak metode dikembangkan sebagai upaya untuk mengeliminasi kontaminasi mikroorganisme selama proses propagasi, Salah satunya adalah dengan menambahkan senyawa anti kontaminan. Antibiotik merupakan pilihan utama yang banyak digunakan. Senyawa ini sangat efektif dalam mengeliminasi mikroorganisme namun sifat fitotoksiknya berpengaruh dalam pertumbuhan dan perkembangan eksplan (Safavi, 2012). Beberapa proses metabolisme utama eksplan akan terhambat seperti sintesis protein, asam nukleat dan membran dinding sel oleh Chloramphenicol, rifampicin dan penicillin. Neomycin dan Streptomycin terbukti menghambat pertumbuhan tunas pada Pelargonium, (Wojtania et al, 2005). Selain itu penggunaan dosis yang relatif tinggi dapat mengakibatkan terjadinya mutasi genetik sehinggga menciptakan bakteri yang resisten terhadap antibiotik, dengan demikian diperlukan penambahan senyawa bioaktif alami yang dapat bersifat menekan laju pertumbuhan mikroorganisme kontaminan.

Centella asiatica merupakan salah satu tumbuhan yang memiliki senyawa bioaktif antifungi dan antibakteri. Senyawa asiaticoside yang terkandung dalam pegagan merupakan antibiotik alami yang banyak terkumpul dibagian daun C. asiatica, selain itu kandungan triterpenoidnya dapat bersifat sebagai antimikrobia dan pelindung tanaman terhadap serangan patogen (Ismaini, 2011)

Anggrek adalah tanaman yang paling banyak dibudidayakan secara kultur in vitro. Ekstrak aquades dan etanol daun $C$. asiatica telah terbukti dapat menghambat laju pertumbuhan fungi patogen pada daun anggrek Bulbhopyllum flavidiflorum (Ismaini, 2011). Ekstrak C. asiatica berpotensi menjadi senyawa alternatif anti kontaminan pada kultur in vitro anggrek. Oleh karena itu dalam penelitian ini dilakukan pengujian efektivitas dan pengaruh penggunaan ekstrak aquades $C$. asiatica sebagai senyawa anti kontaminan dan pengaruhnya terhadap proses perkecambahan anggrek Dendrobium macrophyllum .

\section{Bahan dan Metode}

Penelitian dilaksanakan pada bulan April sampai September 2014 di Laboratorium Kultur Jaringan Fakultas Sains dan Teknologi UIN Sunan kalijaga Yogyakarta.

Bahan tanaman C. asiatica berasal dari Taman Nasional Gunung Merapi. Buah Anggrek Dendrobium macrophyllum umur 4 bulan diperoleh dari Mekar Sari Orchid.

Penelitian ini merupakan penelitian eksperimental dengan 8 perlakuan dan 10 ulangan (Tabel 1).
Tabel 1. Medium perkecambahan D. macrophyllum

\begin{tabular}{cccc}
\hline Medium & Hyponex & $\begin{array}{c}\text { Ekstrak C. } \\
\text { asiatica }\end{array}$ & Yeast \\
\hline A & $1,5 \mathrm{~g} / \mathrm{l}$ & - & 1,25 \\
$\mathrm{~B}$ & $1,5 \mathrm{~g} / \mathrm{l}$ & $5 \%$ & 1,25 \\
$\mathrm{C}$ & $1,5 \mathrm{~g} / \mathrm{l}$ & $10 \%$ & 1,25 \\
$\mathrm{D}$ & $1,5 \mathrm{~g} / \mathrm{l}$ & $15 \%$ & 1,25 \\
$\begin{array}{c}\text { Vaccin } \\
\text { and }\end{array}$ & - & - & - \\
Went & & & \\
\hline
\end{tabular}

\subsection{Ekstraksi Centella asiatica}

Daun C. asiatica yang digunakan adalah daun muda. Sebanyak 1000 gram daun segar dicuci menggunakan air bersih, setelah itu direndam menggunakan fungisida selama 10 menit, dibilas dengan aquades steril 3 kali, kemudian dikeringkan selanjutnya di blender sampai halus. Diambil 50 gram serbuk $C$. asiatica kemudian dilarutkan dalam $500 \mathrm{ml}$ aquadest dan didiamkan selama 24 jam. Setelah itu di keringkan menggunakan oven sampai beratnya konstan. Konsentrasi ekstrak aquadest $C$. asiatica bervariasi pada perlakuan yaitu $5 \%, 10 \%$ dan $15 \%$.

\subsection{Pembuatan Medium Kultur In Vitro}

Medium kultur in vitro yang digunakan dalam penelitian ini adalah medium kultur alternatif yang terdiri dari Pupuk Hyponex hijau dengan konsentrasi 1,5 gr/I serta penambahan yeast (ragi) 1, $25 \mathrm{~g} / \mathrm{I}$ dan penambahan ekstrak aquades $C$. asiatica bervariasi sesuai dengan perlakuan (table 1). Sebagai Kontrol positif digunakan medium Vaccint and Went (VW). Dalam 1 Liter medium ditambahkan ekstrak $C$. asiatica sebanyak $50 \mathrm{ml}, 100 \mathrm{ml}$ dan $150 \mathrm{ml}$. (5\%, $10 \%$ dan $15 \%)$.

\subsection{Penanaman biji Anggrek Dendrobium macrophylum}

Buah Anggrek Dendrobium macrophyllum umur 4 bulan dicuci kemudian direndam menggunakan alkohol 70\%. Setelah itu disterilisasi secara fisik dengan melalukan buah diatas api bunsen sebanyak 3 kali. Buah kemudian dibelah dan biji angrek dikeluarkan untuk kemudian di inokulasi pada medium kultur in vitro dengan perlakuan yang telah disiapkan. Pemeliharaan dilakukan di ruang kultur dengan suhu ruang $21^{\circ} \mathrm{C}$ dan penyinaran menggunakan lampu TL 20 Watt.

Parameter yang diamati meliputi persentase kontaminasi oleh mikroorganisme dalam medium tumbuh dan laju perkecambahan biji anggrek Dendrobium macrophyllum dengan mengamati dan menghitung fase-fase perkecambahan biji yang ditentukan berdasarkan perubahan warna dan ukuran yang terjadi pada eksplan selama 12 minggu. 


\section{Hasil dan Pembahasan}

Berdasarkan penelitian terlihat bahwa medium yang ditambah ekstrak C. asiatica tidak ada yang mengalami kontaminasi. Kontaminasi sampai minggu ke 12 terdapat pada medium kontrol VW dan medium tanpa penambahan ekstrak pegagan. Hal ini menunjukkan bahwa ekstrak aquadest $C$. asiatica dapat mengurangi kemungkinan kontaminasi pada medium tumbuh kultur jaringan. Ekstrak aquadest pegagan mengandung senyawa antifungi yang bersifat toksik seperti flavonoid dan triterpenoid yang tidak menguap dan rusak karena pemanasan (Ismaini, 2011). Selain itu terdapatnya senyawa saponin dalam ekstrak pegagan diketahui memiliki aktivitas antifungi dan menghambat pertumbuhan mikrobia dengan mekanisme perusakan membran sel jaringan organisme kontaminan pada kultur in vitro (Obsourn, 2003).

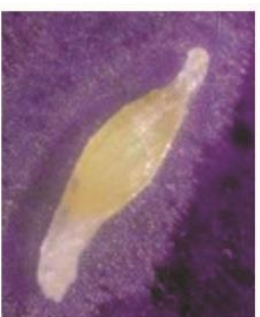

A

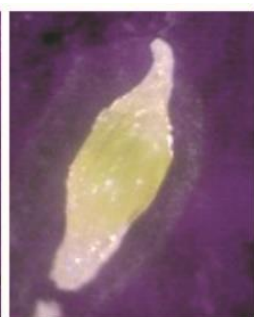

B

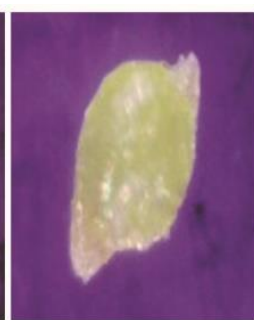

C

Tabel 2. Kontaminas

medium kultur oleh mikroorganisme (bakteri dan fungi) pada perkecambahan biji anggrek Dendrobium macrophyllum.

\begin{tabular}{cccc}
\hline Medium & \multicolumn{3}{c}{$\begin{array}{c}\text { Kontaminasi mikrorganisme } \\
\text { (bakteri dan fungi) }\end{array}$} \\
\hline & $\begin{array}{c}\text { Minggu } \\
\text { ke 4 }\end{array}$ & $\begin{array}{c}\text { Minggu ke } \\
8\end{array}$ & $\begin{array}{c}\text { Minggu ke } \\
12\end{array}$ \\
\hline A & $10 \%$ & $20 \%$ & $30 \%$ \\
B & - & - & - \\
C & - & - & - \\
D & - & - & - \\
$\begin{array}{c}\text { Vaccin } \\
\text { and } \\
\text { Went }\end{array}$ & $10 \%$ & $20 \%$ & $20 \%$ \\
\hline
\end{tabular}

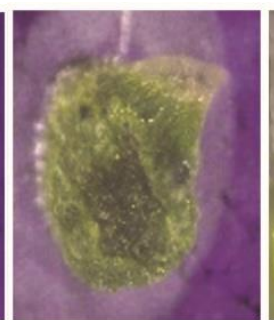

D

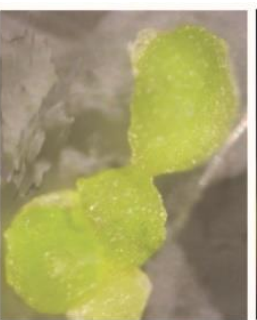

E

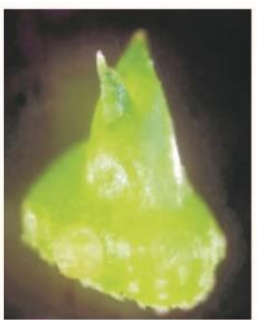

$\mathrm{F}$

Gambar 1. Tahapan perkecambahan biji Dendrobium macrophyllum A. Rich. A. Fase I: Embrio membengkak, tapi masih didalam kulit biji (testa). B. Fase II: sebagian testa telah larut. C. Fase III: embrio sudah lepas dari testa dan embrio membulat. D. Fase IV: belum muncul lekukan, muncul rhizoid. E. Fase V: sudah ada lekukan. F. Fase VI: tumbuh calon daun pertama.

Respon perkecambahan biji anggrek $D$. macrophyllum pada medium Vaccint \& went (kontrol) dan medium hyponex, yeast serta variasi ekstrak pegagan diamati secara periodik setiap 2 minggu sekali. Dari data diperoleh hasil semua biji anggrek $D$. macrophyllum mampu tumbuh dan berkecambah melalui tahapan perkecambahan yang ditunjukkan pada Gambar 1 pada semua perlakuan. Perkecambahan biji anggrek diawali dengan imbibisi, pelepasan embrio dari testa, tumbuhnya rhizoid disusul dengan lekukan dan radikula serta diakhiri oleh kemunculan daun pertama dan kedua (Nerri, 2012).
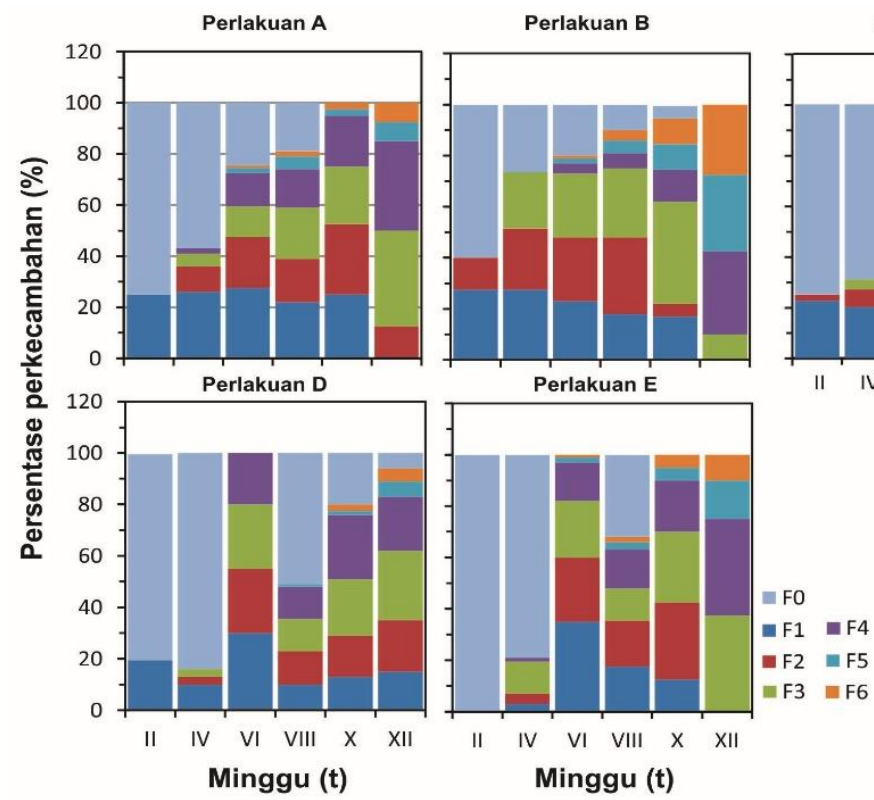

Perlakuan C

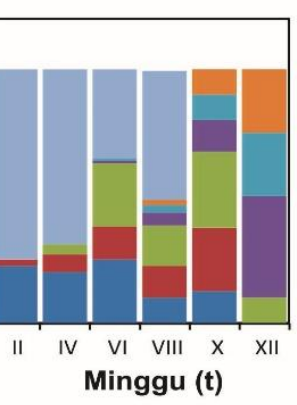

Gambar 2. Persentase perkecambahan biji anggrek D. macrophyllum tiap fase selama 12 minggu. 
Kecepatan pertumbuhan biji anggrek $D$. macrophyllum berbeda pada setiap perlakuan. (Gambar 2). Hal ini dimungkinkan karena komposisi kandungan senyawa organik yang ditambahkan dalam medium perlakuan berpengaruh terhadap inisiasi dan perkembangan perkecambahan biji (Arditti, 1993).

Pada minggu ke 2 setelah penaburan mulai tampak adanya perkecambahan fase 1 di semua perlakuan, kecuali pada medium Vaccin \& went (Kontrol). Bahkan pada perlakuan B dan C tampak sudah ada yang memasuki fase 2 (Gambar 2).

Perlakuan E mulai berkecambah pada minggu ke 4, dalam minggu ini juga dapat ditemukan kecambah pada fase 1, 2 dan 3, hal yang sama tampak pada perlakuan A. Fase perkecambahan yang lengkap dapat ditemukan pada pengamatan minggu ke 6 pada semua perlakuan kecuali perlakuan D. Perlakuan D baru memiliki fase lengkap setelah minggu ke 10. Pada pengamatan minggu terkhir diperoleh data semua perlakuan telah memiliki fase lengkap perkecambahan. Walaupun demikian tetap terdapat perbedaan jumlah fase -fase perkecambahan yang terdapat dalam perlakuan. Pada perlakuan A masih terdapat perkecambahan fase 2 , pada perlakuan $B, C$ dan $E$ terdapat tahapan perkecambahan minimal pada fase 3 sedangkan pada perlakuan D masih dapat ditemui perkecambahan yang termasuk dalam tahap 1.

Secara umum inisiasi awal perkecambahan biji anggrek dipengaruhi oleh penambahan senyawa organik yang ditambahkan berupa yeast dan ekstrak aquades pegagan. Didalam ekstrak yeast terkandung asam -asam amino, vitamin C, thiamin dan Nitrogen yang bermanfaat bagi tumbuhan terutama pada masa awal inisiasi perkecambahan (Widiastoety \& Kartikaningrum, 2003). Ekstrak aquades pegagan yang ditambahkan memberikan respon positif untuk inisiasi awal perkecambahan, hal ini dimungkinkan karena ekstrak pegagan mengandung asam amino, saponin, myo-inositol, meso-inositol yang diduga dapat meningkatkan laju perkecambahan biji anggrek (Sudarsono, 2002). Selain itu pegagan juga mengandung vitamin C, thiamin, sulfat dan kalsium (Seevaratnam et al, 2012). Namun demikian seiring dengan peningkatan konsentrasi ekstrak pegagan yang ditambahkan dalam medium perlakuan tampak bahwa terjadi penurunan laju pertumbuhan, terutama pada penambahan ekstrak pegagan sebanyak 15\%. Hal ini dimungkinkan karena pengaruh senyawa metabolit sekunder yang terkandung dalam ekstrak pegagan seperti flavonoid dan triterpenoid. Senyawa - senyawa tersebut dapat menghambat laju perkecambahan tanaman, hal ini dengan penelitian Gangsar 2010 yang menyatakan pemberian ekstrak pegagan konsentrasi tinggi dapat menyebabkan penurunan laju perkecambahan biji bayam duri dan tomat.

Penyedia unsur hara makro dan mikro lengkap pada medium alternatif ini diwakili oleh pupuk daun hyponex hijau dengan konsentrasi 1,5 g/l. Berdasarkan atas penelitian Shintiavira et al, 2012, pupuk daun hyponex hijau memiliki komposisi unsur hara makro dan mikro yang lengkap sehingga dapat digunakan sebagai alternatif pengganti medium in vitro VW dengan ditambahkan senyawa organik kompleks. Senyawa organik kompleks seperti pepton, yeast dan air kelapa dapat membantu meningkatkan laju perkecambahan biji anggrek (Arditti, 1993). Tidak adanya penambahan senyawa oganik kompleks pada perlakuan kontrol medium Vaccin \& Went diduga sebagai penyebab lambatnya inisiasi awal perkecambahan dibandingkan dengan perlakuan yang lainnya.

Dari Gambar 3 terlihat bahwa pada penambahan yeast dan ekstrak pegagan konsentrasi $5 \%$ dan $10 \%$ memberikan pengaruh pada inisiasi awal perkecambahan, sedangkan pada medium dengan penambahan ekstrak pegagan 15\% dan medium Vaccin \& Went tampak terjadi penghambatan di awal pertumbuhan.

Embrio anggrek tidak membentuk kotiledon, tidak mempunyai endosperm karena degenerasi inti sperma dua, oleh sebab itu diperlukan medium in vitro untuk dapat mengecambahkan biji anggrek dengan optimal. Perkecambahan biji anggrek memerlukan medium tumbuh dengan komposisi nutrien, gula dan penambahan bahan organik tertentu dalam komposisi yang sesuai (Arditti, 1992).

Pada perlakuan dengan penambahan ekstrak pegagan dengan konsentrasi $15 \%$ tampak terjadi penghambatan pertumbuhan pada minggu ke 2 setelah penaburan di masa awal perkecambahan, Penghambatan di awal perkecambahan dimungkinkan karena pengaruh senyawa metabolit sekunder dalam pegagan seperti flavonoid dan triterpenoid yang dapat menghambat laju perkecambahan tanaman jika terdapat dalam konsentrasi yang tinggi. Senyawa ini dapat menyebabkan perubahan permiabilitas membran mitokondria dan kloroplas serta mampu menghambat pembelahan sel pada tanaman (Gangsar, 2010). Pada minggu ke 4 sampai pada minggu ke 12 terjadi peningkatan pertumbuhan protokorm anggrek, walaupun terjadi perlambatan tumbuh namun semua fase pertumbuhan terlewati dalam perlakuan ini. Anggrek termasuk kelompok tanaman yang bersifat recalsitrant sehingga mampu tetap tumbuh dalam senyawa penghambat seperti antibiotik kanamysin konsentrasi tinggi (Mii, 2000). 


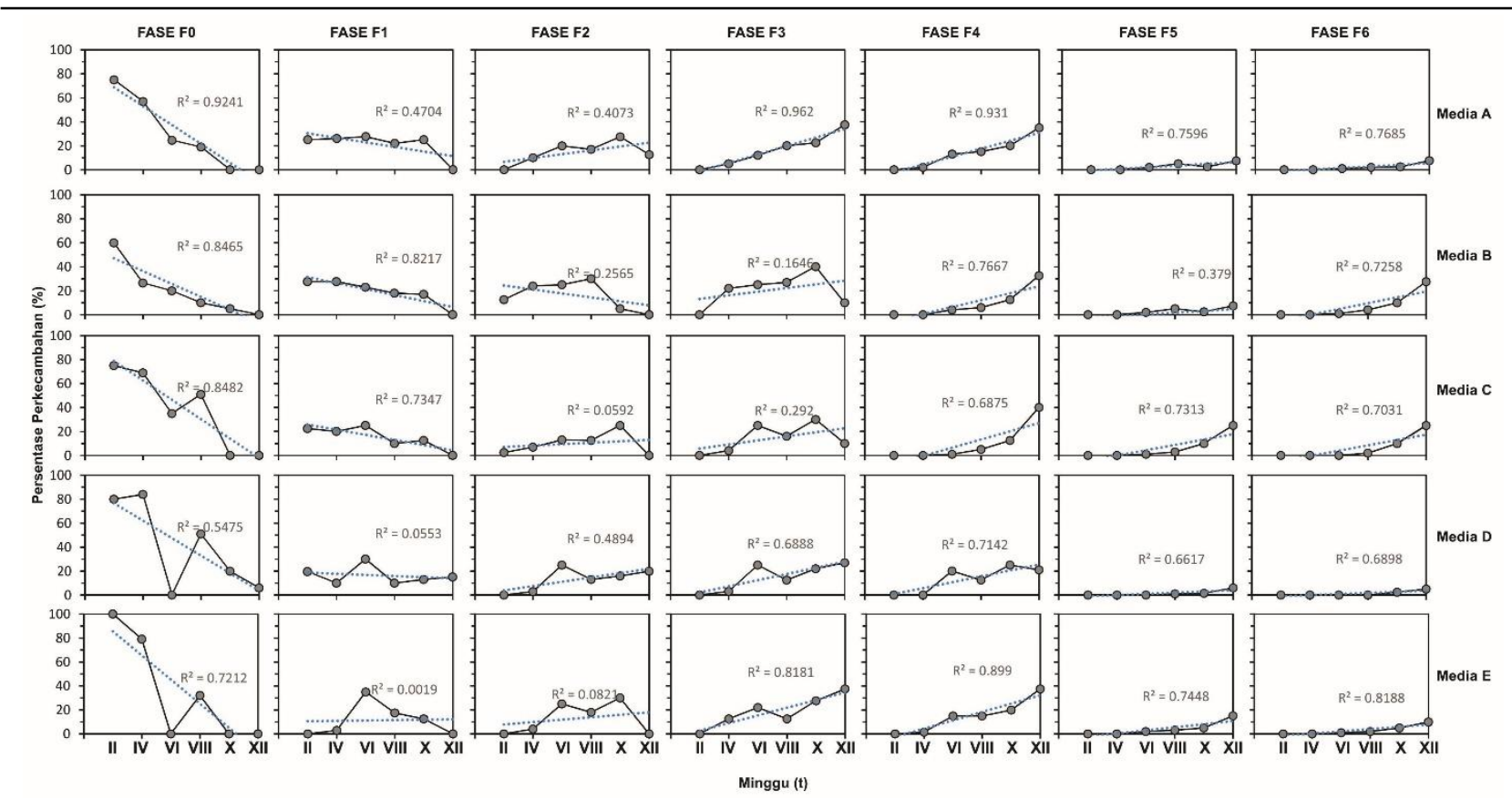

Gambar 3. Pola pertumbuhan perkecambahan biji anggrek $D$. macrophyllum selama 12 minggu

Dari Gambar 4 terlihat perbedaan kondisi protokorm setelah 12 minggu pasca penaburan. Pada perlakuan dengan penambahan ekstrak pegagan $5 \%, 10 \%$ dan $15 \%$ protokorm tetap bisa tumbuh tetapi semakin besar konsentrasi ekstrak yang ditambahkan tampak sedikit menghambat pertumbuhan, hal ini terlihat dari ukuran dan warna hijau protokorm. Sedangkan pada penambahan yeast tampak warna protokorm hijau muda, untuk yang ditumbuhkan di medium VW warna hijaunya tampak lebih pucat dan berukuran lebih kecil -kecil hal ini dimungkinkan karena tidak adanya penambahan senyawa organik komplek kedalam mediumnya sehingga perkecambahan dan tahapannya terhambat. Penambahan senyawa organik komplek seperti air kelapa dan ekstrak tomat diperlukan dalam perkecambahan anggrek secara in vitro (Semiarti, et al, 2010).

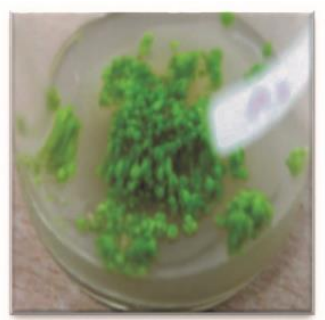

A

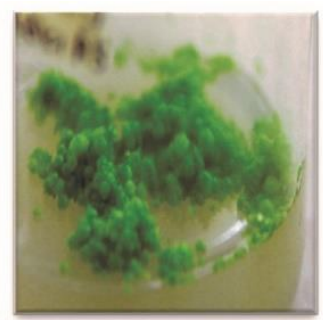

B

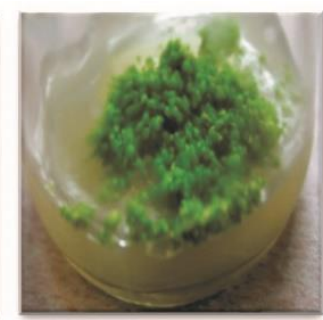

C

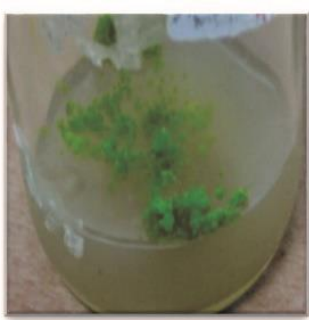

D

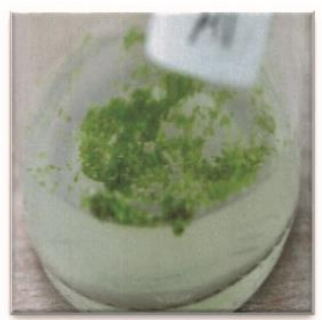

E

Gambar 4. Protokorm Anggrek D. macrophyllum pada medium perlakuan 12 minggu setelah penaburan biji, A. Perlakuan medium hyponex + yeast , B Medium hyponex+ ekstrak pegagan 5\%, C Medium hyponex+ ekstrak pegagan 10\%, D Medium hyponex+ ekstrak pegagan 15\% dan E Medium Vaccin and went

\section{Kesimpulan}

Komposisi media pupuk daun $1,5 \mathrm{~g} / \mathrm{l}$, ekstrak ragi $1,25 \mathrm{~g} / \mathrm{l}$, dan ekstrak daun pegagan $5 \%$ merupakan media optimal untuk perkecambahan biji anggrek Dendrobium macrophylum karena dapat bertahan aseptis, memiliki waktu inisiasi biji berkecambah tercepat, jumlah prosentase perkecambahan terbanyak dan warna protocorm hijau segar.

\section{Daftar Pustaka}

Arditti, J. 1992. Fundamentals of Orchid Biology. John Wiley and Sons. New York . p 73, 144, 155

Arditti, J. and R. Ernst. 1993. Micropropagation Of Orchids: Methods for Specific Genera. New York: John Wiley \& Sons.

Nerri, T. P. 2012. Pengaruh Pemberian Jus Tomat Pada Media Ms, VW, Dan Np Terhadap 
Perkecambahan Biji Phalaenopsis amabilis (L.) BI. InVitro. Skripsi. Fakultas Sains dan Teknologi Universitas Airlangga.

Gangsar, S. R. 2010. Pengaruh Ekstrak Pegagan (Centella asiatica (L) Urban) Sebagai Alelokemi terhadap Perkecambahan dan Pertumbuhan Bayam duri dan Tomat. Skripsi. Fakultas Matematika dan IImu Pengetahuan Alam USM.

Ismaini Lily. 2011. Aktivitas antifungi ekstrak Centella asiatica (L.) Urban terhadap Fungi patogen pada daun Anggrek Bulbophyllum flavidiflorum Carr. Jurnal Penelitian Sains. Vol 14 Nomer 1 (D).

Leifert C, 2000. Quality Assurance Systems for plant Cell and Tissue culture, the problem of latent persistence of bacterial pathogens and Agrobacterium - based transformation vector systems. ACTA Hort. 530:87-91

Mii, M.M Belarmino. 2000. Agrobacterium mediated genetic transformation of Phalaenopsis Orchid. Plant Cell Reports (2000) 19: 435-442.

Osbourn, A.E. 2003. Saponin in cereals. Phytochemistry 62 (1). Diakses 22 mei2016 dari http: //www. sciencedirect. com/ science.

Safavi Kamran, 2012. Evaluation of using nanomaterial in tissue culture media \& biological activity. $2^{\text {nd }}$ International Conference on Ecological Environment and Biological Science (EEBS 2012) Oct 13-14 2012. Bali Indonesia.
Seevaratnam, V., Banumathi, P., Premaltha, M.R., Sundaram, S.P., and Arumugam, T. 2012. Functional Properties of Centella asiatica (I.): a review. International Journal of Pharmacy and Pharmaceutical Sciences 4(5)

Shintiavira. H, Soedarjo, Suryawati, dan Winarto. B. 2012. Studi Pengaruh Subsitusi Hara Makro dan Mikro Media MS dengan Pupul Majemuk dalam Kultur In Vitro Krisan. Jurnal Holtikultura 21(4):332-341.

Semiarti, Endang, A. Indrianto, Y.H Purwantoro, I.N.A Martiwi, Y.M.L Feroniasanti, F.Nadhifah, I.S. Mercuriana, R.Dwiyani, H.Iwakawa, Y. Yoshioka, Y.machida\&C. Machida. 2010. High Frequency Genetic transformation of Phalaenopsis amabilis Orchid using tomato extract enriched medium for the preculture of protocorm. The journal of Horticultural Science and Biotechnology Vol. 85 issues 3, 2010

Sudarsono P., Gunawan, dan D. Wahyono. 2002. Hasil Penelitian Sifat-Sifat Penggunaan. Yogyakarta: Penerbit Pusat Studi Obat Tradisional Universitas Gadjah Mada.

Widiastoety, D dan Kartaningrum S. 2003. Pemanfaatan Ekstrak Ragi Dalam Kultur In Vitro Plantlet Anggrek. Jurnal Hortikultura 13(2): 82-86.

Wojtania Agnieszka, Joanna Pulawska and Gabryzewska, 2005. Identification and elimination of bacterial contaminants from Pelargonium tissue cultures. Journal of fruit and Ornamental Plant Research.Vol 13. 101108 